\title{
INTRACELLULAR TURNOVER OF MUTANT ENZYMES IN LYSOSOMAL STORAGE DISEASES
}

\author{
YOSHIYUKI SUZUKI \\ The Tokyo Metropolitan Institute of Medical Science, Tokyo 113
}

Molecular analysis of genetic metabolic diseases has provided fruitful information about mutant genes and their products in somatic cells. In conventional biochemical analysis, the cells are disrupted mechanically or chemically, and a certain constituent or ingredient is extracted, purified and analyzed for structure and function in physiological or pathological state. However, this approach is valid only for the sum of the dynamic intracellular events at a given moment, and the fate of a specific molecule in the cell is not revealed.

A protein is subjected to various molecular modifications, and transported to exert its function at a predetermined organelle or site. We have been focusing our attention to lysosomes and lysosomal enzymes as a model system to analyze posttranslational changes of normal or mutant protein molecules. The sequence of events occurring intracellularly after the biosynthesis of lysosomal enzymes is listed in Table 1. This paper deals briefly with some recent results of molecular analysis in my laboratory, mainly for mutant proteins in the cells from lysosomal disease patients

\section{ANALYSIS OF MUTANT PROTEINS IN FIBROBLASTS}

For analysis of biosynthesis and processing of lysosomal enzymes, the protein in question was labeled with a radioactive isotope, precipitated with a specific antiserum, separated by electrophoresis, and visualized by fluorography (pulse-chase analysis) (1, 8). It has been particularly useful to analyze dynamic aspects of molecular events involving newly synthesized proteins.

Fibroblasts were cultured and pulse-labeled with ${ }^{3} \mathrm{H}$-leucine in a leucine-free culture medium for a few $\mathrm{hr}$, and the culture was further continued in the same

Correspondence address: Yoshiyuki Suzuki, M. D., The Tokyo Metropolitan Institute of Medical Science, 3-18-22 Honkomagome, Bunkyo-ku, Tokyo 113, Japan. medium without radioactivity (chase). In our laboratory, a few lysosomal enzymes have been studied for posttranslational modification and maturation: $\beta$-galactosidase, $\alpha$-glucosidase and protective protein/carboxypeptidase. Molecular mechanisms of $\alpha$ glucosidase transport and targeting to lysosomes were also analyzed by this method,

$\beta$-Galactosidase activity is partially or completely lost under various molecular and environmental conditions. Two genetically different enzyme molecules have been separated and characterized: $G_{M 1} \beta$-galactosidase encoded by a gene on chromosome 3 , and galactosylceramide $\beta$-galactosidase encoded by another gene on chromosome 14. However, little information is now available for the latter. $\mathrm{G}_{\mathrm{M} 1} \beta$-galactosidase has been the major target of our recent biochemical and genetic research. It is known to interact with another functional protein (protective protein/carboxypeptidase) to form a high-molecularweight aggregate in lysosomes. We prepared an antiserum against the enzyme molecule and another against the complex, and started analysis of intracellular turnover of these two proteins (3-5). Then, we cloned cDNAs coding for human $\mathrm{G}_{\mathrm{M} 1} \beta$ galactosidase (6) and protective protein (9), and subsequently started mutation analysis of human diseases with $\beta$-galactosidase deficiency.

In normal fibroblasts, an $84-\mathrm{kDa}$ precursor was processed first to an $88-\mathrm{kDa}$ intermediate form and then to a $64-\mathrm{kDa}$ mature form (3). The intermediate form was secreted into the culture medium. All $\mathrm{G}_{\mathrm{M1}^{-}}$

TABLE 1. Intracellular turnover of lysosomal enzymes
Transcription
Translation
Posttranslational modification
Translocation
Activation/Stabilization
Degradation 
gangliosidosis cell strains synthesized the precursor, bot no further processing was observed (4). One of them showed a precursor of abnormal molecular mass $(86 \mathrm{kDa})$, which corresponded to a partial duplication of the gene observed in a subsequent study (13). Enzyme deficiency in this disease occurred probably as a result of abnormal protein biosynthesis that was followed by rapid degradation of mutant molecules in infantile $\mathrm{G}_{\mathrm{M} 1}$-gangliosidosis.

An inherited defect of protective protein is expressed clinically as a disease galactosialidosis that is deficient in two lysosomal enzymes, $\beta$-galactosidase and neuraminidase. This strange double enzyme deficiency is caused by defect of protective protein that activates these two enzymes intracellularly. We reported esterase/deamidase deficiency at neutral $\mathrm{pH}$ and carboxypeptidase deficiency at acidic $\mathrm{pH}$. This protein has stabilization/activation function toward lysosomal enzyme proteins as well as catalytic activities toward other compounds as a multifunctional enzyme. The site or mechanism of interaction between protective protein and $\beta$-galactosidase/ neuraminidase is not clear as yet.

\section{INTRACELLULAR TRANSPORT OF NORMAL AND MUTANT PROTEINS}

Some lysosomal enzymes are transported by way of the mannose 6-phosphate receptor system, but some others are not. This pathway is not effective for I-cell disease because of defect in phosphorylation in the carbohydrate moiety of the enzyme molecule. Activities of lysosomal enzymes are therefore reduced to various degrees (Table 2). This variation probably reflects the presence of not less than two different transport

TABLE 2. Lysosomal enzyme activities in I-cell disease fibroblasts

\begin{tabular}{cl}
\hline Relative activity & \multicolumn{1}{c}{ Enzyme } \\
\hline $0-5 \%$ & $\beta$-galactosidase \\
& $\alpha$-fucosidase \\
& arylsulfatase A \\
& $\alpha$-mannosidase \\
& $\alpha$-galactosidase \\
& $\alpha$-iduronidase \\
& $\beta$-hexosaminidase \\
& $\beta$-glucuronidase \\
& $\alpha$-glucosidase \\
& $\beta$-glucosidase \\
& acid phosphatase \\
\end{tabular}

mechanisms. We analyzed $\alpha$-glucosidase and $\beta$-hexosaminidase in this disease $(10,11)$.

About $70 \%$ of the $\alpha$-glucosidase activity is preserved in fibroblasts, and mixed leukocytes preserved their activity. Although $\beta$-hexosaminidase activity was almost completely lost in heavy lysosomes as determined by Percoll density gradient centrifugation, $\alpha$ glucosidase was transported there almost normally in I-cell disease fibroblasts. Furthermore, $\beta$-hexosaminidase activity was localized in heavy lysosomes in transformed lymphoblasts in spite of defective phosphorylation of mannose residue in the enzyme molecule. At present we do not know the molecular mechanism of the alternative transport system in I-cell disease.

\section{MUTANT GENE AND ITS EXPRESSION PRODUCT}

We recently identified numerous mutations in four types of primary $\beta$-galactosidase deficiency $(\beta$ -

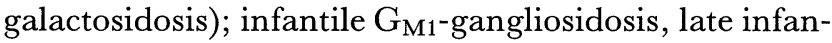

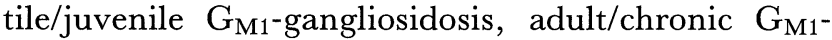
gangliosidosis and Morquio B disease $(7,13)$. They express phenotypic manifestations of different severity and pathological distribution. Gene expression studies revealed almost complete loss of enzyme activity except for specific and common mutations in three of them; mutation A (I51T) in adult/chronic $\mathrm{G}_{\mathrm{M}^{-}}$gangliosidosis, mutation B (R201C) in late infantile/juvenile $\mathrm{G}_{\mathrm{M} 1}$-gangliosidosis and mutation $\mathrm{F}$ (W273L) in Morquio B disease. Each of them was expressed in a fibroblast strain completely deficient in enzyme activity, and the processing and intracellular localization were studied. Mutant enzymes disappeared at the early stage of processing with defect in phosphorylation, degraded rapidly in lysosomes due to defect in aggregate formation with protective protein, or changed substrate specificity (Oshima, A. et al., unpublished data; Table 3). These specific abnormalities in molecular modification and/or translocation may be clearly associated with phenotypic expressions. Histochemical or electron microscopic investigations have not been performed on these molecules as yet. Morphological approaches will reveal more details of pathological molecular mechanisms in the future.

We have been trying another approach for analysis of mutant proteins using various expression systems in culture. The baculovirus system was useful for producing a large amount of gene products. However, in an overexpression experiment of human $\beta$-galactosidase, the distribution of the enzyme molecule between cells and culture medium was found 
TABLE 3. Gene mutations and abnormalities in mutant proteins in human $\beta$-galactosidase deficiency

\begin{tabular}{|c|c|c|c|c|c|}
\hline \multirow{2}{*}{\multicolumn{2}{|c|}{ Phenotype $^{\text {a) }}$}} & \multirow{2}{*}{ Genotype $^{\mathrm{b})}$} & \multicolumn{2}{|c|}{ Enzyme } & \multirow{2}{*}{$\begin{array}{l}\text { Substrate } \\
\text { Storage }^{\mathrm{e})}\end{array}$} \\
\hline & & & Turnoverc) & Activityd) & \\
\hline \multicolumn{6}{|l|}{ I. Neurosomatic } \\
\hline Generalized & $\mathrm{G}_{\mathrm{M} 1} / \mathrm{inf}$ & Hetero & Hetero & - & $\mathrm{G}_{\mathrm{M} 1}, \mathrm{OS}>\mathrm{KS}$ \\
\hline \multicolumn{6}{|l|}{ II. Neuroskeletal } \\
\hline Generalized CNS & $\mathrm{G}_{\mathrm{M} 1} / \mathrm{juv}$ & R201C & Aggregation & + & $\mathrm{G}_{\mathrm{M} 1}>\mathrm{OS}>\mathrm{KS}$ \\
\hline Localized GNS & $\mathrm{G}_{\mathrm{M} 1} /$ adult & $\mathrm{I} 51 \mathrm{~T}$ & Processing & + & $\mathrm{G}_{\mathrm{M} 1}>\mathrm{OS}>\mathrm{KS}$ \\
\hline \multicolumn{6}{|l|}{ III. Skeletal } \\
\hline Generalized & Morquio B & W273L & Normal & + & $\mathrm{KS}, \mathrm{OS}>\mathrm{G}_{\mathrm{M} 1}$ \\
\hline
\end{tabular}

a) CNS: central nervous system, $\mathrm{G}_{\mathrm{M} 1}$ : $\mathrm{G}_{\mathrm{M} 1}$-gangliosidosis, inf: infantile form, juv: late infantile/juvenile form, adult: adult/chronic form.

b) Hetero: heterogeneous mutations. Each of the R201C and I51T mutations is common to a specific clinical form of $\beta$-galactosidase deficiency in Japanese patients.

c) Hetero: heterogeneous. Aggregation: defect of aggregation with protective protein, resulting in abnormal breakdown of the enzyme molecule. Processing: phosphorylation defect probably due to abnormal glycosylation. Normal: normal translocation and turnover, with abnormal substrate specificity.

d) - : not detectable, + : detectable.

e) Amount of tissue storage or urinary excretion. $\mathrm{G}_{\mathrm{M} 1}$ : ganglioside $\mathrm{G}_{\mathrm{M} 1}$, OS: oligosaccharides, KS: keratan sulfate.

to be different from that for human fibroblasts (2). Glycosylation seems to be slightly different although it occurs in this insect cell culture system. We have to take into consideration the cell species for evaluation of normal and mutant molecules in the research of intracellular events using culture cells.

Molecular analysis is in itself a useful technique to evaluate the intracellular events but there is a limitation for information about transport or localization of gene products. Histochemical and electron microscopic approaches will overcome this disadvantage of analytical procedures.

\section{ACKNOWLEDGMENTS}

I wish to thank my colleagues at the Department of Clinical Genetics, The Tokyo Metropolitan Institute of Medical Science for their achievements in molecular analysis of lysosomal diseases. This work was supported by grants from the Ministry of Education, Science and Culture and the Ministry of Health and Welfare of Japan.

\section{REFERENGES}

1. Hasilik, A. and Neufeld, E. F.: Biosynthesis of lysosomal enzymes in fibroblasts. Synthesis as precursors of higher molecular weight. J. Biol. Chem. 255;
4937-4945, 1980.

2. Itoh, K., Oshima, A., Sakuraba, H. and Suzuki, Y.: Expression, glycosylation, and intracellular distribution of human $\beta$-galactosidase in recombinant baculovirus-infected Spodoptera frugiperda cells. Biochem. Biophys. Res. Commun. 167; 746-753, 1990.

3. Nanba, E., Tsuji, A., Omura, K. and Suzuki, Y.: Galactosialidosis: Direct evidence that a 46-kilodalton protein restores deficient enzyme activities in fibroblasts. Biochem. Biophys. Res. Commun. 144; 138-142, 1987.

4. Nanba, E., Tsuji, A., Omura, K. and Suzuki, Y.: $\mathrm{G}_{\mathrm{M}^{-}}$ gangliosidosis: Abnormalities in biosynthesis and early processing of $\beta$-galactosidase in fibroblasts. Biochem. Biophys. Res. Commun. 152; 794-800, 1988.

5. Nanba, E., Tsuji, A., Omura, K. and Suzuki, Y.: Galactosialidosis: Molecular heterogeneity in biosynthesis and processing of protective protein for $\beta$-galactosidase. Hum. Genet. 80; 329-332, 1988.

6. Oshima, A., Tsuji, A., Nagao, Y., Sakuraba, H. and Suzuki, Y.: Cloning, sequencing, and expression of cDNA for human $\beta$-galactosidase. Biochem. Biophys. Res. Commun. 157; 238-244, 1988.

7. Oshima, A., Yoshida, K., Shimmoto, M., Fukuhara, Y., Sakuraba, H. and Suzuki, Y.: Human $\beta$-galactosidase gene mutations in Morquio B disease. Am. J. Hum. Genet. 49; 1091-1093, 1991.

8. Proia, R. L., D'Azzo, A. and Neufeld, E. F.: Association of $\alpha$ - and $\beta$-subunits during the biosynthesis of $\beta$-hexosaminidase in cultured human fibroblasts. J. Biol. Chem. 259; 3350-3354, 1980.

9. Shimmoto, M., Takano, T., Fukuhara, Y., Oshima, A., Sakuraba, H. and Suzuki, Y.: Japanese-type adult galac- 
tosialidosis. A unique and common splice junction mutation causing exon skipping in the protective protein/carboxypeptidase gene. Proc. Japan Acad. 66B; 217-222, 1990.

10. Suzuki, Y., Sakuraba, H., Yamanaka, T., Ko, Y.-M., Iimori, Y., Okamura, Y. and Hoogeveen, A. T.: Galactosialidosis: A comparative study of clinical and biochemical data on 22 patients. In "The Developing Brain and Its Disorders", ed. by Arima M, Suzuki Y, Yabuuchi H, Karger, Basel, 1985, pp. 161-175.

11. Tsuji, A., Omura, K. and Suzuki, Y.: I-cell disease: Evidence for a mannose 6-phosphate independent pathway for translocation of lysosomal enzymes in lymphoblastoid cells. Clin. Chim. Acta 176; 115-122, 1988.

12. Tsuji, A., Omura, K. and Suzuki, Y.: Intracellular transport of acid $\alpha$-glucosidase in human fibroblasts: Evidence for involvement of phosphomannosyl receptorindependent system. J. Biochem. 104; 276-286, 1988.

13. Yoshida, K., Oshima, A., Shimmoto, M., Fukuhara, Y., Sakuraba, H., Yanagisawa, N. and Suzuki, Y.: Human $\beta$-galactosidase gene mutations in $\mathrm{G}_{\mathrm{M} 1}$-gangliosidosis: $\mathrm{A}$ common mutation among Japanese adult/chronic cases. Am. J. Hum. Genet. 49; 435-442, 1991. 